\title{
"O ARQUIVO TOTAL DA HUMANIDADE": UTOPIA ENCICLOPÉDICA E DIVISÃO DO TRABALLHO NA ETNOLOGIA FRANCESA*
}

\author{
Benoît de L'Estoile \\ Ecole Normale Supérieure - França
}

Resumo: O presente artigo mostra como, na primeira metade do século $X X$, os esforços dos fundadores da antropologia francesa visavam a organizar e racionalizar o sistema de divisão do trabalho do conhecimento pela separação e coordenação entre cientistas acadêmicos e etnógrafos voluntários. Esse sistema contrasta com a imagem romântica e mais corriqueira do antropólogo isolado, e que corresponde ao caso britânico, no qual se deu um esforço no sentido da inserção do cientista no campo e a "profissionalização" foi acompanhada da exclusão dos "amadores", relegados a um estado obsoleto da atividade de investigação. O modelo de divisão do trabalho, dominante na França, exigiu o recrutamento de "multidões de colaboradores" e favoreceu o estabelecimento de uma rede que articulava disciplinarmente os profissionais da antropologia e os auxiliares coloniais.

Palavras-chave: divisão do trabalho intelectual, história da antropologia, profissionalização, trabalho de campo.

Abstract: During the first half of the twentieth century, the efforts made by the founding fathers of French anthropology aimed at organizing and rationalizing the scientific labor division system, by separating and coordinating academic scientists from voluntary ethnographers. This whole system is very different from the romantic, and more common, view of the isolated anthropologist, an image that corresponds to the British case. In Britain, efforts were made for the scientist to be in the field; "professionalization" was simultaneous to the exclusion of all "amateurs," the latter being left to an obsolete state of investigative activity. The

\footnotetext{
* Uma versão inicial deste texto foi apresentada em novembro de 1999, no colóquio do Centre de Recherches Historiques (Centro de Pesquisas Históricas), da Ecole Pratique des Hautes Etudes en Sciences Sociales, sobre pesquisa coletiva em ciências sociais no século XX. Agradeço a Florence Weber por sua leitura.
}

Horizontes Antropológicos, Porto Alegre, ano 9, n. 20, p. 265-302, outubro de 2003 
labor division model, dominant in France, required that "a huge mass os collaborators" be recruited, and it also favored the founding of a network that put the anthropology professionals in a disciplinary relation to all colonial assistance.

Keywords: field work, history of anthropology, intellectual labor division, professionalization.

A antropologia com frequiência se apresenta, hoje em dia, como uma disciplina muito individualista. Vários etnólogos cultivam a imagem romântica do pesquisador isolado em terreno distante, num tête-à-tête consigo mesmo e com seus informantes "indígenas". $\mathrm{O}$ que parece caracterizar esse modo de conhecimento, por oposição às demais ciências sociais, é notadamente seu baixo grau de divisão do trabalho: o antropólogo se apresenta como aquele que essencialmente trabalha com dados recolhidos por ele mesmo em investigação direta, e não com dados já construídos por outros ${ }^{2}$. Essa representação, que se impôs a ponto de, hoje, ser tomada como ponto pacífico, é, no entanto, relativamente recente na França. Pretendo apresentar aqui um modelo alternativo de pesquisa, baseado na divisão do trabalho, que estruturou a antropologia francesa na primeira metade do século XX. Ele teve seu apogeu nos anos 30, e permite compreender certo número de traços institucionais e intelectuais que marcam esse domínio do saber - em alguns casos, até os dias de hoje.

Hoje em dia, na França, considera-se que a antropologia pertence inteiramente às ciências sociais, e ela tem seu lugar numa escola que lhes é consagrada $^{3}$. No entanto, contrariamente a um mito bem arraigado nas histórias da disciplina, sua inclusão entre as "ciências sociais" no período entre guerras é muitíssimo mais problemática. Dito de outra forma (e isso é repetidamente deixado de lado, atualmente), o mesmo nome cobria então,

\footnotetext{
${ }^{1}$ Expressivo da força desse modelo é o fato de que, mesmo em suas reflexões estimulantes sobre as novas condições do fieldwork, vários antropólogos britânicos considerem unicamente as pesquisas individuais ou em dupla. Ver Dresch, James e Parkin (1999).

2 Assim também o fazem, em sua maioria, os sociólogos quantitativistas, geógrafos e economistas. Quanto aos historiadores, eles geralmente utilizam arquivos preexistentes.

${ }^{3}$ Ver as contribuições de Jean Bazin (1996) e Philippe Descola (1996) à obra coletiva precisamente intitulada Une Ecole pour les Sciences Sociales [Uma Escola para as Ciências Sociais], de J. Revel e N. Wachtel.
} 
para esse saber, uma definição distinta da nossa. A antropologia, na versão que se impôs na França no decorrer dos anos 30, foi essencialmente o projeto de uma Ciência do Homem em sua totalidade, concebida como um "ramo das ciências naturais" que reunia a um tempo a antropologia física, a pré-história e a etnografia ${ }^{4}$. Segundo Rivet, ao definir em 1936 "o que é a etnologia", essa concepção "se afirma na França de um modo material pela criação de um Museu do Homem onde as raças, as civilizações e as línguas serão estudadas paralelamente e solidariamente" (Rivet, 1936). Essa referência ao modelo das ciências naturais tem conseqüências determinantes para o tipo de organização do trabalho que se implementou.

Apresentarei aqui o lado francês de um trabalho comparativo com a Grã-Bretanha, onde um modelo bem distinto se impôs. Para simplificar, pode-se dizer que na Grã-Bretanha a revolução científica que se deu em torno de Malinowski consistiu precisamente numa redefinição da divisão do trabalho estabelecida no século XIX entre a etnografia, ciência descritiva, e a antropologia, saber especulativo e comparativo. Os anthropologists, que tinham por base os museus ou as instituições científicas, eram teóricos que procuravam reconstituir "a história natural da humanidade", reunindo, classificando e comparando, tal como peças de um vasto quebra-cabeça, "dados" de todo tipo (objetos, costumes, vocabulários, crânios, etc.) e das mais diversas proveniências. A instituição que encarnava essa organização do trabalho era o Royal Anthropological Institute of Great Britain and Ireland, que reunia todos os que se interessavam, de perto ou à distância, pelos diversos aspectos da "Science of Man", e que publicava questionários (os Notes and Queries in Anthropology, regularmente reeditados) e também uma revista, Man, construída precisamente como uma coleção de "fatos" (cada entrada numerada, que podia ocupar entre algumas linhas e várias páginas, era dedicada a "observações" ou descrições - de um rito, de um mito, de uma técnica, etc.). O coração da revolução malinowskiana foi

\footnotetext{
4 "De todos os ramos das ciências naturais, a etnologia é, em virtude de seu objeto mesmo, a mais complexa. Os diversos aspectos que o estudo de qualquer grupo humano apresenta são tão marcados e diferenciados que dão por vezes a impressão de concernir a ciências distintas; mas o fato é que toda pesquisa antropológica, para ser realmente completa, deve refleti-los todos." Este é o início do manifesto de Paul Rivet (1936). Essa definição marca até hoje a estrutura das instituições antropológicas francesas, como a seção 38 do CNRS [o Centro Nacional de Pesquisa Científica francês], "Unidade do homem e diversidade das culturas" ou o CNU [o Conselho Nacional das Universidades, na França], "Pré-história, antropologia, etnologia".
} 
a supressão dessa disjunção entre os teóricos e os que vão a campo. A antropologia em novo estilo combina as duas competências, teoria e informação: os papéis do etnógrafo e do antropólogo são desempenhados pela mesma pessoa. Essa revolução na divisão do trabalho resulta numa marginalização dos etnógrafos coloniais, desqualificados como "amadores". Ao mesmo tempo, a antropologia se torna uma "ciência social", o que significa que a antropologia social se autonomiza em relação a uma antropologia "generalista" que reunia antropologia física, pré-história, etc. ${ }^{5}$

$\mathrm{Na}$ França, todos os esforços dos fundadores da disciplina etnológica no período entre guerras visavam, pelo contrário, a organizar e racionalizar o sistema de divisão do trabalho do conhecimento, para dar-lhe mais eficácia. Eu gostaria de tentar mostrar aqui tanto os princípios essenciais desse sistema, os esforços para pôr em prática aquilo que se poderia chamar uma utopia científica, no sentido de racionalizá-lo, quanto alguns de seus efeitos nos saberes produzidos ${ }^{6}$.

\section{Os princípios da divisão do trabalho: observadores e estudiosos eruditos}

Em 1932, o Bulletin de la Société des Recherches Congolaises, impresso em Brazzaville pelo governo geral da África Equatorial Francesa (AEF), publica uma carta de Lucien Lévy-Bruhl, datada de 5 de dezembro de 1931, na qual este agradece por receber o boletim dessa sociedade científica colonial:

Encontro aí com freqüência documentos interessantes para meus trabalhos. Em A Alma Primitiva, por exemplo, e em $O$ Sobrenatural $e$ a Natureza na Mentalidade Primitiva, fiz uso de observações preciosas devidas ao padre Walker. Vocês me fariam um grande favor transmitindo a ele que me é de grande proveito lê-lo [...] e dizendolhe que ficarei contente se ele puder ter a bondade de me comunicar as observações inéditas que ele sem dúvida tem em seu poder. (LévyBruhl, 1932, p. 115).

\footnotetext{
5 Sobre essas transformações, ver L'Estoile (1997).

${ }^{6}$ Abordo, aqui, apenas de modo indireto a questão do vínculo - determinante para a estruturação do saber - com o contexto colonial. Permito-me remeter o leitor às minhas análises em L'Estoile (2000, 2001).
} 
Essa carta, bem como sua publicação, são reveladoras de uma forma de organização do trabalho que caracteriza então as pesquisas sobre as sociedades ditas "primitivas" ou "arcaicas". O estudioso é, antes de tudo, um teórico - filósofo, como Lévy-Bruhl, ou sociólogo, como Emile Durkheim e Marcel Mauss $^{7}$ - que procura nos trabalhos de correspondentes coloniais como Walker $^{8}$ as "observações" necessárias ao seu trabalho. Nesse sentido, podese dizer que a obra "individual" do estudioso já é, na realidade, coletiva, na medida em que pressupõe a existência de "colaboradores" diretos ou indiretos, reconhecidos ou ignorados, e um sistema de circulação das informações.

Essa situação é portanto caracterizada simultaneamente por uma separação radical entre o "campo" longínquo, onde se encontram os observadores, e o "gabinete" (isto é, a biblioteca), onde o estudioso prossegue em suas investigações, e por uma dependência deste vis-à-vis àqueles. O valor de seu trabalho, com efeito, depende estreitamente da qualidade dos "dados" de que dispõe, que são por natureza inacessíveis à sua inquirição direta. LévyBruhl e Mauss concedem assim grande importância à discussão da confiabilidade das diversas "fontes".

Para simplificar, poderíamos resumir a tendência, ao longo da primeira metade do século XX, como um esforço para passar do estágio "artesanal" da divisão do trabalho, em que cada estudioso tem seus próprios correspondentes, àquilo que se poderia chamar uma forma de "organização científica do trabalho", com a constituição de uma vasta rede institucionalizada. É interessante observar, quanto a esse ponto, a evolução de Mauss. Num primeiro momento, na ocasião de sua aula inaugural na Ecole Pratique des Hautes Etudes, em 1902, ele enfatiza o trabalho de crítica dos "documentos", inspirando-se explicitamente no método filológico: trata-se inicialmente de agrupar "documentos esparsos", por um trabalho bibliográfico e sistemático", e de proceder em seguida à crítica das fontes, o que permite encontrar, por

${ }^{7}$ Como lembra J. L. Fabiani, os "sociólogos" durkheimianos permanecem "filósofos" por muito tempo. É também o caso, na França, dos antropólogos.

${ }^{8}$ O padre indígena André Raponga Walker terá longa carreira etnológica, pois em 1949-50 é um "informante" de G. Balandier sobre o culto bwiti, dos fangs do Gabão. Ver Balandier (1950, p. 80$)$.

9 "Os fatos são extremamente esparsos; o conjunto das fontes é ainda pouco conhecido. Nosso esforço aqui será o de suprir, através de um trabalho conjunto, aquilo que ainda falta aos etnógrafos, esse manual completo com indicações bibliográficas completas para cada grupo social estudado." (Mauss, 1969, p. 365). 
comparação de variantes, o "autêntico fato" que é o ponto em questão. Dito de outro modo, o "fato social" não é diretamente "observado", é descoberto; ele é descoberto pelo estudioso a partir de um trabalho de análise dos "documentos" de que dispõe $\mathrm{e}^{10}$.

Sempre mantendo essa exigência crítica, Mauss vai cada vez mais se dedicar também a melhorar a qualidade dos dados "na fonte", esforçandose por suscitar observações orientadas e por formar aqueles que as coligirão ${ }^{11}$. Os guias ou manuais de pesquisa estabelecidos pelas sociedades científicas, como os famosos Notes and Queries, editados pelo Royal Anthropological Institute desde $1877^{12}$, visavam precisamente reduzir o risco de bias, propondo, para tanto, protocolos padronizados que pudessem ser utilizados, com perda mínima de informações, por investigadores sem muito preparo, e evitassem, sobretudo, que estes se vissem levados a interpretar por conta própria ${ }^{13}$. Ao se dirigir, em 1902, a "todos os que não são etnógrafos profissionais", Mauss colocava como primeiro princípio: "É preciso ser estritamente verídico ou objetivo, abstendo-se de apreciações bem como de omissões" (Mauss, 1969).

Mas Mauss vai mais longe, e propõe a criação de uma nova instituição, um "Bureau de Etnografia". Em 1913, denunciando a exigüidade dos trabalhos etnográficos sobre as colônias francesas em comparação com outros países, ele defende com não menos vigor a criação de um "fórum de ensino, de pesquisas, de arquivos, de coleta, de controle" no qual

nossos missionários de todas as confissões, nossos funcionários de todas as ordens, nossos colonos, nossos médicos e oficiais do exército colonial encontrariam hospitalidade quando de seu regresso, instruções

\footnotetext{
10 Sabemos que para os durkheimianos a etnografia é uma "ciência descritiva" que fornece à análise sociológica os materiais empíricos, ao lado da história e da estatística. É notável constatar esse modelo de divisão do trabalho entre observadores no campo e sociólogos expresso em termos tão semelhantes por Halbwachs, em 1930, quando em visita junto aos sociólogos de Chicago; ele os considera antes de tudo como "coletores de fatos", conforme escreve à sua mulher: "mergulhados na vida, em contato estreito com os grupos, eles parecem ignorar totalmente todas as nossas teorias. Estão quanto a isso na mesma situação que os exploradores e missionários em relação a Durkheim" (apud Marcel, 1999, p. 57).

11 Já em 1902, ele esboça um Ensaio de Instrução para o Estudo Sociológico das Sociedades Indo-Chinesas, onde anuncia a publicação próxima de instruções detalhadas (Mauss, 1969).

12 Ver Kuklick (1992, cap. 2).

13 Para um resumo, ver a introdução Le Terrain des Sciences Humaines em Blanckaert (1993).
} 
quando da partida, ajuda constante durante todo o tempo que consagrassem a esses estudos, uma recompensa quando trouxessem seu butim científico. (Mauss, 1969).

Mauss dá como modelo os serviços etnográficos de alguns governos coloniais britânicos, especialmente na Índia e na Nigéria:

Eles não se limitam a destacar etnógrafos para observação e coleta; centralizam e dirigem os trabalhos daqueles que residem nas áreas afastadas, mantêm-lhes o zelo; classificam e registram os documentos provenientes da atividade do pessoal fixo ou do ocasional. Em suma, servem não somente como centros de iniciativa, mas também como arquivo e "seção histórica". (Mauss, 1969, p. 426).

Nesse projeto, a tarefa de observação e de coleta de documentos é, portanto, delegada ao pessoal colonial presente no campo, em particular os agentes do Estado; só se faz necessário orientar-lhes o olhar e enquadrarlhes o zelo. Com efeito, prossegue Mauss,

[...] Não carecemos absolutamente de observadores. Não há funcionários coloniais mais aptos a compreender o indígena e mais íntimos com ele do que nossos administradores, nossos oficiais, nossos médicos. [...] Não há estudiosos que estejam a tal ponto livres de preconceitos - tão perigosos nesses estudos de raça e de religião. [...] Essa boa vontade ignorada, esses sábios que se ignoram não carecem de mais que um impulso, uma ajuda, uma direção. (Mauss, 1969, grifo meu).

A referência à ausência de "preconceitos" é importante: ela, com efeito, sublinha que os observadores não serão tentados a "interpretar" os fatos que estarão encarregados de observar, correndo com isso o risco de os "falsear"

14 É certamente interessante comparar esse vibrante elogio com a condenação inapelável dos "amadores" por Malinowski, alguns anos mais tarde: "[...] quando um negociante, funcionário ou missionário estabelece relações ativas com os nativos é para transformá-los, influenciálos ou usá-los, o que torna impossível uma observação verdadeiramente imparcial e objetiva e impede um contato aberto e sincero [...]" (Malinowski, 1963, p. 75 [N. de T.: o trecho citado aparece aqui conforme a tradução brasileira, por Anton P. Carr, de Os Argonautas do Pacífico Ocidental, p. 29]). 
Retardado pela guerra ${ }^{15}$, esse projeto se viu parcialmente realizado com a fundação, em 1925, do Institut d'Ethnologie [Instituto de Etnologia]. O primeiro objetivo deste era, com efeito, definido por Lévy-Bruhl nos seguintes termos:

1. Formar etnólogos profissionais e dar também as instruções necessárias a todos aqueles que, habitando as colônias ou destinados a fazêlo, têm inclinação pelos estudos etnográficos ou lingüísticos, de modo que possam conduzir tais estudos de modo útil. Pôr os futuros administradores, médicos coloniais, missionários, etc., se estes o desejarem, em condições de realizar boas observações etnográficas, de obter de modo adequado estampagens, clichês, filmes, fonogramas, de saber registrar as línguas, recolher textos, etc. (Lévy-Bruhl, 1925, p. 2).

Vê-se que, além de a formação de "etnólogos profissionais" (sic) não excluir a preparação dos observadores para o trabalho de coleta de dados no campo, esta constitui tarefa fundamental do Instituto de Etnologia. É precisamente a ela que Mauss se dedica, oferecendo semanalmente "instruções de etnografia descritiva para viajantes, administradores e missionários" O Instituto de Etnologia também se volta para a difusão, no mundo colonial, de questionários destinados à coleta de objetos, bem como de dados lingüísticos e etnográficos.

A difusão de tais modelos de investigação no interior do mundo colonial passa, em primeiro lugar, por indivíduos que têm papel de retransmissores. Evocarei, aqui, três casos dentre muitos outros. Esses retransmissores são, em primeiro lugar, estudiosos que atuam como mediadores entre o universo colonial de que provêm e o universo da ciência metropolitana ao qual acederam: é o caso de Henri Labouret, antigo militar e, depois, administrador na África Ocidental Francesa, que vem a se tornar professor de etnografia e de lingüística africanas na Escola Colonial e na Escola Nacional de Línguas Orientais Vivas, e que ensina no Instituto de Etnologia. Ele concebe, em atenção ao que denomina "coorte paciente e modesta de pesquisadores e

15 Lévy-Bruhl evoca o fato de que esse bureau dera lugar a um projeto de Mauss, acolhido por L. Liard.

${ }^{16}$ Foi a partir das notas dos que assistiram esse curso nos anos 30 que Denise Paulme editou e publicou, sob o título de Manuel d'Ethnographie [Manual de Etnografia] (Mauss, 1989), as "instruções" sempre prometidas por Mauss. Vamos aqui nos apoiar amplamente nessas instruções, muito ricas a respeito do "método de pesquisa" do Instituto de Etnologia. 
observadores no campo", um plano extremamente detalhado de monografia regional descritiva, publicado em várias revistas coloniais; ele assim precisa o objetivo de suas instruções:

Destinadas aos administradores, missionários e colonos, elas tendem a obter deles coleções bem ordenadas de fenômenos concretos, reportados com o máximo de exatidão e de detalhes. (Labouret, 1932).

É bem o paradigma da coleção que se impõe também à observação dos fenômenos sociais. Para que um objeto ou um fato possa constituir um "dado" útil ao qual se aplique um procedimento de seriação, é necessário e suficiente que ele seja obtido segundo um protocolo padronizado.

Outro exemplo de retransmissor, agora nas colônias: Maurice Prouteaux, vice-governador em exercício de Ubangui-Chari [África Equatorial Francesa], membro de várias sociedades científicas, e que a partir de 1931 adere à Sociedade dos Africanistas ${ }^{17}$. Ele cria, em 1930, um "Comitê Local de Estudos Científicos e Históricos de Ubangui”, ao qual propõe que os administradores redijam, a partir de suas observações, "fichas" sobre os fatos etnográficos e naturais daquele território ${ }^{18}$. A reunião dessas fichas permitiria, assim, constituir uma "Enciclopédia de Ubangui". Prouteaux sugere igualmente recorrer a pessoas que conheçam bem as línguas indígenas para que preencham os questionários lingüísticos do Instituto de Etnologia ${ }^{19}$. Ele também distribui a seus subordinados conselhos para observações etnográficas que considera úteis ao progresso da ciência ${ }^{20}$.

O último caso, dentre muitos outros que se poderia evocar: o do administrador-chefe Alfred Poupon, membro da Sociedade dos Americanistas desde 1912 e secretário-geral da jovem Sociedade de Pesquisas Congolesas, a mesma à qual Lévy-Bruhl dirigiu os agradecimentos citados anteriormente. Ele trabalha no boletim dessa sociedade e nele publica, em 1931, uma exposição dos "métodos atuais em matéria de etnologia" (Poupon, 1931), que

${ }^{17}$ É diante da Sociedade dos Africanistas que ele se entrega a uma defesa da etnografia: "Quelques exemples de l'utilité pratique des études ethnologiques" [Alguns exemplos da utilidade prática dos estudos etnológicos]. Ver Prouteaux (1932).

18 É provável que a criação desse comitê não esteja desvinculada da preparação da exposição colonial de Vincennes, assim como a da Sociedade dos Africanistas.

19 Lévy-Bruhl pedira no ano anterior a colaboração das administrações para fazer o levantamento preciso do estado lingüístico das colônias.

${ }^{20}$ Ver Bureau des Affaires Politiques de l'AEF [Archives]; ver também Prouteaux [Documentos pessoais]. 
constitui um guia de pesquisa dirigido a seus colegas administradores, inspirado no ensinamento de Mauss, cujo curso, no Instituto de Etnologia, Poupon acompanhou. É dele, no ano seguinte e no mesmo boletim, uma longa "análise das notas de etnografia neo-caledônia de M. Leenart (sic)", na qual se propõe expor "as principais idéias etnográficas que poderão servir de exemplos e de pontos de partida para outras pesquisas" (Poupon, 1932), fazendo várias aproximações com a AEF. Na longa notícia por ele escrita a respeito do Congresso de Etnografia da Exposição Colonial de Paris $^{21}$ e publicada no número seguinte daquele boletim, ele faz eco às palavras de Labouret, que sublinhava que "o papel mais importante não cabe, no momento, aos estudiosos de gabinete, mas aos observadores quotidianos da vida indígena" (p. 93-97). Estes, com efeito, ocupam um lugar estratégico nesse modelo de produção de conhecimentos.

\section{Paradigma naturalista e epistemologia da coleta}

O papel essencial desempenhado nessa configuração pelos observadores no campo aparece nitidamente na segunda missão atribuída ao Instituto de Etnologia: "Atrair a atenção para os fatos recentemente descobertos e para os métodos novos, de modo a solicitar a verificação, no campo, das hipóteses atualmente em discussão." (Lévy-Bruhl, 1925, grifo meu).

Em bom método experimental, são as observações que permitem confirmar ou invalidar as hipóteses discutidas entre os cientistas. A particularidade dessa situação é que, nesse caso, devido à distância do local de experimentação, a observação deve ser delegada. Poder-se-ia falar aqui de empirismo por procuração. Todo o problema está em assegurar a "confiabilidade" dos "fatos" e em excluir aqueles "suspeitos" - os recolhidos por observadores pouco dignos de crédito ou cegados por seus preconceitos. Lévy-Bruhl desenvolve assim um autêntico discurso do método, que deve permitir que se estabeleçam os fatos "certos" - pois que controlados - a partir de simples "testemunhos".

Só o estudo paciente e minucioso da vida social e individual dos primitivos, de suas instituições, suas crenças, seus costumes, suas línguas, permitirá discernir se sua mentalidade possui princípios próprios,

21 Trata-se na verdade do Congresso do Instituto Internacional das Línguas e Civilizações Africanas, em outubro de 1931. 
que a tornam diferente da nossa. Contudo, nesse exame, grandes precauções são necessárias. Os fatos de que se trata não são por nós conhecidos de modo tão satisfatório quanto aqueles com os quais trabalham a física, a química, a biologia e outras ciências da mesma ordem. Eles só nos são dados sob a forma de relatos, documentos, recordações, numa palavra: testemunhos de qualidade não raro medíocre, seja por negligência ou inexperiência dos autores, seja por qualquer outra razão.

[...] que valor podem ter esses testemunhos para a ciência? Não será ao menos necessário, antes de usá-los, submetê-los a uma crítica cerrada, e confrontá-los com outros de que se tem certeza?

Se, portanto, um primeiro exame dos fatos, baseado em documentos dignos de crédito e devidamente controlados, confirmar a hipótese de que a mentalidade primitiva apresenta características que a distinguem nitidamente da nossa, estaremos doravante autorizados a descartar fatos recolhidos por observadores que, possuídos de convicção contrária, os deformaram involuntariamente ou os apresentaram de modo inexato. Os fatos serão, então, selecionados. Mas essa escolha nada terá de arbitrário. Ela consiste simplesmente - e nada mais conforme às regras de um bom método - em não utilizar dados tornados suspeitos em função da prenoção, quase sempre inconsciente, daqueles que os recolheram. (Lévy-Bruhl, 1931, p. 9-10, grifo meu).

É preciso insistir no fato de que, num tal sistema de divisão do trabalho, o lugar do observador de campo, ainda que frequientemente qualificado de "modesto", é fundamental, pois apenas ele está em condições de fornecer as "provas" que decidirão da verdade dos construtos teóricos. Esse sistema valoriza, assim, os "colaboradores", que podem com razão ter a sensação de participar da elaboração da ciência, ao menos na medida em que aceitam seguir as instruções que lhes são dadas. É notável que a etnografia seja recomendada como prática científica particularmente acessível, ao contrário da antropologia física, que, por exigir equipamento e competência técnica, é mais frequientemente reservada aos médicos. Assim, segundo Edouard de Martonne, em 1930, “a etnografia colonial é um ramo ao qual uma colaboração útil é facilmente trazida por qualquer observador consciencioso: a documentação é bem fácil de se obter, ainda que seja necessário submeterse a certas regras simples que foram justamente codificadas pelo Instituto de Etnologia" (Martonne, 1930, p. 41-42). Esse ponto é ainda afirmado por Théodore Monod, em 1953: 
ETNOLOGIA: Pode-se colaborar, sem paquímetro nem craveira, para o estudo das culturas, materiais ou não. É um dos domínios em que o observador sedentário, que conhece bem sua região, pode trazer uma contribuição toda especial à ciência africana. [...] Mesmo os simples apontamentos descritivos (por exemplo, sobre determinado ofício, seus instrumentos e procedimentos) serão sempre preciosos, contanto que exatos (com croquis ou fotografias, dimensões dos objetos, etc.). (Monod, 1954).

Tal modelo de organização da pesquisa não é próprio dos saberes antropológicos. Ele é, ao contrário, como sublinha Mauss em 1913, tomado de empréstimo às ciências naturais, que fornecem o paradigma das "ciências de observação" (ou "ciências descritivas"), opostas às ciências "de laboratório" (ou "ciências experimentais"):

Uma ciência de observação exige três tipos de trabalho, e três tipos de instituição: como as demais ciências ao ar livre - a zoologia, a botânica, a geologia e a geografia física -, a etnografia necessita antes de mais nada de trabalhos de campo, a seguir de museus e arquivos, e enfim de ensino. Necessita um corpo de etnógrafos, profissionais ou amadores, pouco importa, mas que fazem observação in loco e com seus próprios olhos, que fornecem os documentos e recolhem os materiais de coleção. Uma vez coletados esses materiais, é nos museus, nos serviços de arquivo que eles devem ser dispostos, expostos, publicados. Enfim, os ensinamentos de graus diversos devem pôr a ciência ao alcance dos técnicos, dos aprendizes, ou mesmo do grande público. (Mauss, 1969, p. 420, grifo meu).

A série de criações institucionais que marca o período entre guerras e culmina com a criação do Museu do Homem pode ser vista como uma aplicação desse programa que Mauss esboça em 1913, compondo aquela estrutura em níveis, baseada numa epistemologia naturalista. Essa importância do paradigma naturalista não chega a surpreender. É preciso lembrar, com efeito, que a etnologia é institucionalmente construída, na França, de modo bastante amplo, a partir do Museu Nacional de História Natural (MNHM). Da cadeira de antropologia do museu, para a qual é escolhido em 1928, Paul Rivet, médico militar e, a seguir, assistente de Verneau no museu 
(a partir de 1909), se põe a reorganizar a ciência do Homem²2. Rivet, já secretário da Sociedade dos Americanistas, tem papel preponderante na criação da Sociedade dos Africanistas, em 1930. Essas diferentes sociedades científicas têm sede no museu, e aí se reúnem. Rivet se torna, em 1932, secretário-geral do Instituto de Etnologia (vinculado simultaneamente à Faculdade de Letras e à de Ciências). É ao Museu Nacional de História Natural que está ligado o Museu de Etnografia do Trocadéro ${ }^{23}$. Aqueles vinculados ao Museu de Etnografia são, administrativamente, assistentes do MNHN, e Georges-Henri Rivière, encarregado de reorganizar aquele, tem o título de "subdiretor de laboratório".

Esse modelo naturalista esclarece a respeito de duas características solidárias da organização científica da antropologia: o paradigma da "coleta" e a divisão do trabalho. O fundamento epistemológico desse sistema de divisão do trabalho científico é a possibilidade de dissociar duas operações: de um lado, o levantamento dos "dados" no campo, que pode ser realizado por viajantes, missionários e agentes coloniais; de outro, a classificação desses dados e o estabelecimento de relações entre eles - operação reservada aos estudiosos metropolitanos ${ }^{24}$. Esses "dados" podem ser das mais diversas categorias: observações de cenas da vida cotidiana, objetos, anedotas, índices cefálicos, provérbios ou contos recolhidos, notas sobre "costumes" ou julgamentos de tribunais indígenas, registros de músicas ou de línguas não conhecidas, receitas mágicas, descrições de tatuagens ou de patologias específicas, fotografias, etc.

Uma das características desse paradigma naturalista, portanto, é o fato de que a produção de conhecimento está fundada numa divisão bastante marcada do trabalho científico. O MNHN, sob a Terceira República, se esforça em tirar partido da expansão colonial, desenvolvendo uma rede de correspondentes nas colônias ${ }^{25}$. Christophe Bonneuil indica que, nas ciências naturais, o recurso a correspondentes diminui no início do século XX. Essa rede, não obstante, se preserva como um modelo para a antropologia. É espantoso, desse ponto de vista, que se possa retomar termo a termo, com

\footnotetext{
22 Ver Jamin (1989).

23 O Museu do Homem [criado em 1937, substituindo o Museu de Etnografia no mesmo lugar - o Trocadéro] é, até hoje, uma dependência do Museu de História Natural. Parte dos protestos suscitados recentemente pelo projeto de transformação do Museu do Homem está ligada precisamente a essa situação. Ver L'Estoile (2003).

24 Ver Blanckaert (1993).

25 Ver Bonneuil (1999).
} 
respeito à etnografia do período entre guerras, aquilo que Marie-Noëlle Bourguet afirma a propósito da relação do viajante com o naturalista do século XVIII: "Ele é a mão que recolhe os objetos, o olho que os observa e os descreve, como que para permitir que o naturalista, permanecendo na Europa, veja e trabalhe à distância." (Bourguet, 1993).

Em particular, o lugar considerável que é dado à coleta de objetos etnográficos pode ser mais bem compreendido se se leva em conta que eles são concebidos segundo o modelo do espécime. As coleções etnográficas são, assim, o equivalente das coleções de $\operatorname{crânios}^{26}$ ou de animais empalhados, ou dos herbários do museu. Pode-se também fazer um paralelo entre, de um lado, a valorização dos objetos etnográficos, na epistemologia do Museu de Etnografia, como testemunhos mais confiáveis que as descrições e, de outro, a preferência de Cuvier pelo "objeto bruto, crânio ou osso", mais fiel que as observações dos viajantes (Bourguet, 1993).

Essa concepção do objeto etnográfico, calcada no modelo de um "exemplar" ou "amostra" que toma sentido dentro de uma "série", é formulada de modo explícito pelo naturalista Théodore Monod, então diretor do Instituto Francês da África Negra (IFAN), em Dakar, e antigo assistente no MNHN27:

5. Nada é negligenciável, nem mesmo o menor objeto (a semente de tal árvore, ou tal fóssil, ou aquela pedra talhada), nem o menor fato (a temperatura dessa fonte, a data de chegada daquele pássaro ou o número de seus ovos, a ação da tempestade ou da seca nesta planta, a associação daquele inseto com esta flor). Tudo é interessante, tudo é útil. 6. Mas sob condição de ser exato, corretamente observado, verdadeiro; e isso não é tão simples: nós pouco (e mal) sabemos olhar...

7. O mais belo exemplar de planta, de animal, de rocha, de objeto etnográfico, perde todo seu interesse se não estiver acompanhado de uma etiqueta: data e local de coleta, no mínimo; se possível, nome indígena (em que língua?), população de origem (para os objetos), emprego, etc., etc. (Monod, 1954) ${ }^{28}$.

\footnotetext{
${ }^{26}$ Um dos elementos em jogo na construção do Museu do Homem é precisamente a aproximação das coleções "antropológicas" e "etnográficas". As vitrines do museu consagradas às diferentes etnias põem, lado a lado, crânios, fotografias e objetos etnográficos.

${ }^{27}$ Monod, que até avançada idade percorreu o Saara à procura de novas espécies de flora ou de insetos para o museu, encarnou o paradigma do naturalista de campo que se consagra ao inventário do mundo.

${ }^{28}$ Ainda que a tiragem original dessa brochura de "conselhos aos pesquisadores" seja ignorada, o número de reedições indica que, para o IFAN, ela concernia a uma tarefa importante.
} 
Assim, em 1953, é ainda o paradigma naturalista da coleta de objetos e de "fatos" que inspira esses "conselhos aos pesquisadores", dirigidos aos "correspondentes" do IFAN, herdeiros dos viajantes naturalistas ${ }^{29}$.

Desse modo, tal como os objetos ou as borboletas, os "fenômenos sociais" também podem ser "recolhidos" isoladamente, na medida em que forem convenientemente identificados. O essencial está na etiqueta, e na "ficha" descritiva que deve sempre acompanhar o objeto ${ }^{30}$. Isso não quer dizer que um fato isolado tenha, por si, uma significação. A inteligibilidade dos fenômenos sociais não se constrói no campo, e sim no gabinete ou no museu, pela crítica dos documentos e o estabelecimento de relações com outros fenômenos - o que permite que o estudioso acadêmico construa os "fatos sociais" ${ }^{1}$. O zelo documental na coleta de informação está menos ligado ao cuidado com o contexto do que a uma atenção dirigida à origem, à localização e à proveniência, e essa atenção está por sua vez ligada - o próprio Mauss é testemunha - às preocupações museográficas e também a uma retórica da prova.

Aquele que coleta se dedicará a compor séries lógicas, reunindo para isso, se possível, todos os exemplares de um mesmo objeto, segundo as dimensões, formas, textura. A localização é absolutamente necessária; sem ela, o objeto não pode entrar em nenhum museu.

Cada objeto receberá um número escrito a tinta, remetendo ao inventário e a uma ficha descritiva, fornecendo informações sobre o uso e fabricação do objeto. A ficha descritiva será acompanhada de vários anexos, em particular um anexo fotográfico e, se possível, um anexo cinematográfico. [...] Anotar-se-ão de modo muito preciso as datas de emprego, já que certos objetos têm valor sazonal [...]; um objeto pode ainda ser empregado apenas por homens, ou apenas por mulheres. (Mauss, 1989, p. 17).

29 "O bom viajante é aquele cujo olhar, perfeitamente fiel, observa e comunica aquilo que vê, cuja mão, precisa, hábil no ato de colher, exata no de descrever, é capaz de fazer dos espécimes coletados objetos lisíveis e transmissíveis, pois que devidamente calibrados e etiquetados." (Bourguet, 1993, p. 176-177).

${ }^{30}$ As Instruções Sumárias do IFAN (Monod, 1954) dão em apêndice um modelo de ficha para os objetos etnográficos, as coleções de mamíferos e os peixes.

31 Essa concepção certamente se opõe de modo radical à concepção malinowskiana do conjunto funcional, na qual cada fenômeno ganha sentido em sua relação dinâmica com os outros.

Horizontes Antropológicos, Porto Alegre, ano 9, n. 20, p. 265-302, outubro de 2003 
Esse modelo da coleta estrutura na verdade toda a atividade antropológica. Mais especificamente, é notável que as observações dos alunos do Instituto de Etnologia na ocasião da estada no campo fossem feitas em "fichas", classificadas tematicamente e destinadas aos diferentes fenômenos da vida social ${ }^{32}$. O trabalho etnográfico, portanto, consiste em "fichar", literalmente, o conjunto da sociedade estudada.

É preciso, enfim, evocar a relação entre essas práticas de coleta e o emprego recorrente do termo "arquivo", que parece remeter mais ao modelo de erudição histórica do que ao paradigma naturalista. Mauss, com efeito, apresenta da seguinte forma suas recomendações etnográficas: "daremos as instruções necessárias para constituir cientificamente os arquivos dessas sociedades mais ou menos arcaicas" (Mauss, 1989, p. 7). E ele afirma adiante que "a museografia de uma sociedade consiste em formar-lhe o arquivo material; os museus são arquivos" (Mauss, 1989, p. 16). Para além da insistência na acumulação e conservação - o que aproxima o arquivo do museu -, essa fórmula revela uma dimensão fundamental para a concepção da etnografia então em vigor ${ }^{33}$. Por serem "sem escrita", as "sociedades arcaicas" estudadas pela etnografia não têm - por definição - "arquivos". Enquanto que o historiador trabalha com arquivos preexistentes, este termo tem necessariamente, para a etnografia, um sentido metafórico: arquivos não se podem constituir senão do exterior, pela etnografia e, em particular, a museografia. De que modo então constituir "documentos" que possuam o mesmo caráter de "prova" que os arquivos têm para os historiadores? A importância atribuída aos objetos e à sua conservação nos museus está fundamentalmente ligada à necessidade de minorar os efeitos dessa ausência de vestígios escritos que possam servir como "prova" 34 .

Se os museus podem ser identificados aos arquivos, não é unicamente por serem um local de conservação, mas também no sentido cartorial de "local das provas" (os cartórios atestam, dão fé) e no sentido histórico de "lugar da

\footnotetext{
32 Ver carta de Denise Paulme a Michel Leiris, de 16/5/35: "Eu recomendo, se lhe interessar, as fichas HOGON-PROCES-VERBAL [Hogon-processo-verbal], que se encontram no maço 11. [...] Se a literatura obscena entre os Dogon interessar a você, recomendo as fichas CHANSON-FONIO [canção-fonio - fonio é uma variedade de milho de grãos miúdos]: cantamnas (sic) ao colher o cereal." (Paulme, 1992). A correspondência de Denise Paulme, na ocasião em que estava em pesquisa de campo, em Sanga, constitui um extraordinário documento sobre as práticas de investigação, que não raro contrasta com as prescrições metodológicas. Agradeço a Adam Kuper por indicar-me essa obra rara.

33 Ver Jamin (1988).

34 "O objeto é em muitos casos a prova do fato social." (Mauss, 1989, p. 9).
}

Horizontes Antropológicos, Porto Alegre, ano 9, n. 20, p. 265-302, outubro de 2003 
verdade". É assim que se pode compreender a frase de Mauss: "As coleções de museu continuam a ser o único meio de escrever a história" (Mauss, 1989, p. 17). A história - subentende-se - das sociedades que, não tendo arquivos escritos, são sem "história" e pertencem ao domínio da "pré-história"35.

Mas, assim como o Estado é encarregado da conservação dos arquivos, por ser o guardião do passado nacional, também esse acúmulo de "arquivos das sociedades" faz parte, para Mauss, dos deveres em que a França incorreu para com as civilizações cuja "proteção" ela assumiu.

A França tem um dever quase sagrado. Ela tem obrigações para com os grupos humanos que quer administrar sem conhecer; ela tem obrigações com a ciência para a qual não conserva os dados; ela tem obrigações para com as gerações vindouras de colonos e de indígenas assimilados, para os quais não serão constituídos os arquivos e acervos que poderiam permitir-lhes formar uma representação do passado. (Mauss, 1969, p. 433).

Essa tripla responsabilidade pertence plenamente à missão de um "grande povo". É precisamente essa dimensão de conhecimento que faz a dominação francesa superior à da antiga Roma. Sem ela, assinala Mauss, há o risco de que, no futuro "o historiador, diante das lacunas que a França terá deixado na descrição dos povos, diga: 'a França tratava seus súditos como as nações antigas aos Bárbaros”” (1969, p. 434).

A etnografia deve, assim, desempenhar o papel de uma "história das sociedades sem história". Nas práticas acadêmicas coloniais, de fato, ela é com freqüência associada à história, entendida antes de mais nada como crônica da conquista. Desse modo, a noção de "arquivo" remete ainda à idéia de que aqueles que escreverão a história devem poder utilizar os materiais coligidos por outros.

Indo além dos objetos, a obsessão pela recolha de "documentos" no campo transparece também no modelo proposto por Mauss, de coleta folclorística e filológica: “[...] Um bom método de trabalho será o filológico, que consiste em colher a princípio contos, reunindo coleções de variantes (exemplo: a primeira edição dos contos de Grimm)."

\footnotetext{
35 Ao mesmo tempo, o termo "arquivo das sociedades" é característico dessa abordagem descritiva, fundamentalmente estática, que caracteriza a museografia e a etnografia.
} 
Dito de outra maneira, trata-se de estabelecer "textos" que são os "documentos brutos" para um trabalho filológico ulterior ${ }^{36}$. Essa coleta documentária (de contos, mas também de provérbios, de fórmulas mágicas ou religiosas, etc.) obedece ainda, portanto, a uma lógica muito próxima da coleta de objetos.

Dir-se-á, no entanto, que os anos 30 viram a invenção da "antropologia de campo", fato recentemente celebrado por uma exposição no Museu do Homem, em homenagem a Marcel Griaule e à missão Dakar-Djibuti ${ }^{37}$. Na verdade, mais que uma alternativa, essas grandes "expedições etnográficas" itinerantes, das quais Dakar-Djibuti é a mais famosa, podem ser vistas como uma variante dentro do paradigma naturalista. Com efeito, elas são concebidas segundo o modelo das grandes expedições naturalistas do século XIX, que acompanharam as viagens de exploração ${ }^{38}$. Esse modelo está explícito em Mauss:

O ideal seria que uma missão não partisse sem seu geólogo, seu botânico e seus etnógrafos. Reduzir-se-iam assim as despesas gerais; por outro lado, um antropólogo pode se revelar sociólogo, e todos podem ser excelentes museógrafos. Portanto, vários devem partir juntos. (Mauss, 1989, p. 16)

Assim, a expedição Griaule, que percorre a África de Dakar ao Djibuti para aí recolher "fatos" de todo tipo e, acima de tudo, objetos, é o equivalente, para a etnografia, do que foram as viagens de Humboldt ou Darwin no século anterior, ou mais precisamente a expedição antropológica do estreito de Torres, organizada em 1898 pela Universidade de Cambridge ${ }^{39}$.

36 O modelo filológico também está presente em Malinowski, por exemplo com a noção (na qual não há ironia) de Corpus inscriptionum Kiriwiniensum, nos Argonautas. Em seguida, no entanto, ele denuncia o erro que consiste em tratar as enunciações como "textos" (Malinowski, 1965).

37 Exposição no Museu do Homem, de 14 de outubro a 31 de dezembro de 1998: L'Afrique de Marcel Griaule (1898-1956). Centenaire d'un pionnier de l'ethnographie française [A África de Marcel Griaule - Centenário de um pioneiro da etnografia francesa].

38 Ao mesmo tempo, ela também deve ser comparada à expedição [de André] Citroën na Ásia Central ("expedição amarela"), que parte no mesmo momento; é significativo que o chefe dessa expedição, Haardt, também receba incumbência do Instituto de Etnologia.

39 Ver Stocking (1996). 
No cerne dessas expedições, a dimensão coletiva da pesquisa passa por outro tipo de divisão do trabalho, agora baseada na especialização. É essa, segundo Griaule, a característica de uma ciência moderna e eficaz, cuja metodologia ele expõe ao retornar da expedição, em 1933.

Essa certeza, assim como essa rapidez, será encontrada na divisão do trabalho interna a uma equipe de observadores especializados e atuando em contato permanente. [...] O etnógrafo faz-tudo é uma concepção antiquada. Quem não tem senso jurídico deve abster-se de observar o direito [...]; quem não tem ouvido para línguas não se obstinará em registrá-las. (Griaule, 1933).

Essa exigência de "especialização" de cada observador em função de suas "competências" próprias admite, na prática, certa flexibilidade: ela permite integrar "colaboradores" que não têm "competência" bem definida, como é o caso da maioria dos membros das expedições de Griaule ${ }^{40}$. Uma carta de Déborah Lifchitz a Michel Leiris, na época da missão Saara-Sudão (1935), descreve o modo como essa divisão do trabalho é colocada em prática na chegada da expedição aos Dogon:

Colocamo-nos a trabalhar, pois já reencontramos todos os antigos informantes [...] Griaule trabalha com eles e com um olubaru; ele descobriu algumas cavernas com inscrições, que lhe foram explicadas. Paulme faz o recenseamento do baixo Ogol, a Sra. de Breteuil se ocupa de etnobotânica, Larget da topografia musical, Lutten explora as cavernas, Gordon ${ }^{41}$ indaga sobre a binuya e a yapilu; quanto a mim, ocupo-me de lingüística. [...] (Paulme, 1992 [carta - de D. Lifchitz - de 8/2/1935]).

${ }^{40}$ Em seu Método de Etnografia, obra póstuma (Griaule, 1957) que retoma o curso proferido na Sorbonne a partir de 1942, Griaule faz ainda a apologia da pesquisa em equipe, em que se recorre a especialistas de diferentes disciplinas. Assim, "uma equipe composta de um historiador das religiões, de um lingüista, de um naturalista e de um médico" pode dar "excelentes resultados". Com efeito, ele prossegue, "os especialistas serão úteis de duas formas: cada um trará a sua ciência abordagens novas e originais; aplicará seus métodos ao estudo etnográfico do conjunto, o que aumentará a qualidade dos resultados".

${ }^{41}$ Hélène Gordon, posteriormente Lazareff, fundadora de Elle. Ela escreve para Paris-soir uma série de artigos sobre os Dogon: No antro dos demônios bebedores de sangue (Paulme, 1992 [nota]). 
Tal organização do trabalho coletivo pressupõe a participação de certo número de indígenas como informantes (e remunerados como tal). Estes têm, portanto, um status complexo, sendo "auxiliares" da investigação da qual são também (na qualidade de representantes do grupo pesquisado) os "objetos".

A dimensão coletiva da investigação aparece também como garantia de objetividade e de qualidade científica. Em face de uma cerimônia complexa como os funerais, afirma Griaule, o observador solitário não dá conta da multiplicidade de ações simultâneas. Diferentes observadores, colocando-se em pontos estratégicos, podem, por outro lado, dividir entre si o trabalho. Nas reuniões, supostamente cotidianas, cada um faz seu relato: "A menor dúvida dá lugar a duas verificações, no mínimo - as dos dois colaboradores em contradição -, e é raro que, com isso, não se lance luz rapidamente sobre a questão." (Griaule, 1957) ${ }^{42}$. De modo mais específico, a dimensão coletiva dá uma superioridade decisiva ao pesquisador em sua defrontação com os informantes, os quais, conforme a concepção policial que Griaule desenvolve acerca da investigação, procuram sempre dissimular o essencial ${ }^{43}$ : "Seu conhecimento cada vez mais aprofundado [...] lhe dá um faro cada vez mais difícil de surpreender, na constituição de seu arquivo. E isso é percebido por seu parceiro - seu adversário - indígena." (Griaule, 1957, p. 23).

Essa dupla caracterização do informante, simultaneamente parceiro e adversário, indica bem a ambivalência de seu estatuto, à margem da equipe de pesquisa propriamente dita.

É preciso sublinhar que essa teorização do trabalho coletivo remete a uma experiência efetiva: as missões de Griaule reuniram sistematicamente várias pessoas, e o trabalho acumulado sobre os Dogon do Sudão francês figura como um exemplo de pesquisa coletiva; ele se estende por quase 30 anos (e prosseguiu mesmo bastante tempo depois da morte de Griaule), a ponto de esse grupo se ter tornado uma espécie de "totem" da etnologia africanista francesa ${ }^{44}$.

${ }^{42}$ Essa vantagem da operação de "averiguação" também é sublinhada por Mauss (1989).

${ }^{43}$ Ver especialmente o esquema "zonas de segredo próprias a cada informante" (Griaule, 1957, p. 23, Fig. 2).

${ }^{44}$ Ver o balanço feito por Germaine Dieterlen (1959). 
Cooperacão e centralização: um pequeno exército de trabalhadores auxiliares

$\mathrm{Na}$ medida em que não esgotam a ampla tarefa de inventariar as sociedades humanas, as expedições de pesquisadores que realizam pessoalmente a coleta de dados não vêm tornar obsoleto o modelo de divisão do trabalho com base nos relés (controladores) locais ${ }^{45}$, Tais expedições são antes o complemento desse modelo, e uma das tarefas que lhes são consignadas é precisamente a de assegurar a ligação entre a ciência metropolitana e aqueles que devem tornar-se seus "correspondentes" locais. Na definição oficial das missões da expedição Dakar-Djibuti, importância considerável é conferida a essa função de racionalização das práticas científicas coloniais:

estabelecer contato com os meios coloniais e dar aos elementos que demonstram boa vontade diretivas que lhes permitam realizar observações segundo métodos racionais e reunir coleções utilizáveis cientificamente. (IFAN, 1931)

É com esse objetivo que o instituto faz imprimir as Instruções Sumárias para os Coletores de Objetos Etnográficos (IFAN, 1931) ${ }^{46}$, que também insistem sobre o papel fundamental da "boa vontade" dos voluntários da periferia na construção de uma ciência nacional.

Para restituir a nosso Museu de Etnografia o lugar que lhe cabe entre os grandes museus do mundo, basta que os que vivem ou circulam longe da metrópole, funcionários, viajantes, turistas ou colonos se disponham a nos ajudar a formar coleções.

Em comunicação direta e diária com os habitantes das regiões que percorrem ou habitam, eles são os mais bem situados para recolher, junto com os objetos, todos os detalhes relativos a estes e reunir assim - através de informações orais ou escritas, por desenhos ou fotografias - uma mina de documentos que multiplicarão o interesse científico dos objetos recolhidos.

\footnotetext{
45 Da mesma forma, as expedições naturalistas não suprimem, ipso facto, o papel das remessas de exemplares pelos "estudiosos" de campo.

46 Instructions Sommaires pour les collecteurs d'objets ethnographiques. Segundo Jamin (1989, p. 284), essa brochura foi redigida por Griaule e Leiris. Ela parece inspirar-se no ensino de Mauss.
} 
Orientar as pesquisas dos colecionadores, fornecer-lhes um método de trabalho, dar-lhes diretivas racionais conforme as disciplinas autorizadas - este é o objetivo das presentes instruções. (IFAN, 1931, p. 7, grifo meu).

Essas instruções continuam a ser difundidas ao longo dos anos 30, como mostra a correspondência das administrações coloniais com o museu ${ }^{47}$.

Os promotores do Museu do Trocadéro procuram inspiração nos museus coloniais de países vizinhos: é assim que Rivière convida Maes, curador do Museu do Congo Belga, em Tervuren, para uma grande conferência na prestigiosa sala Pleyel, em Paris.

Tenho a satisfação [...] de poder ouvir sua conferência: todos aqui se interessarão por suas explicações quanto à organização de vosso belo museu, o recrutamento metódico para as coleções, em ligação com os funcionários, missionários, etc., seus métodos de classificação e de exposição, e tudo mais que lhe aprouver relatar sobre a etnografia do Congo Belga. (Carta de Rivière a Maes, 29/1/1931 - Biblioteca do Museu do Homem).

O que está em jogo é o desenvolvimento e a estruturação da rede de observadores no campo. Para esquematizar, pode-se dizer que os anos 30 vêem a passagem de um modelo de organização, que se pode qualificar de "federativo", a um modelo "centralizado".

As sociedades científicas, concebidas como "relés" entre as práticas científicas locais e as instituições centrais, ocupam um lugar estratégico nessa divisão do trabalho de conhecimento. O propósito de Rivet, que procura unificar o espaço da etnologia numa só organização tentacular, pode ser assim resumido: passar de uma nebulosa de instituições mais ou menos autônomas e concorrentes, na metrópole e nas colônias, a uma rede estruturada e hierarquizada. Desse ponto de vista, um dos aspectos a serem notados na criação da Sociedade de Africanistas, em 1930, é a implementação de uma espécie de "correia de transmissão" entre cientistas metropolitanos e mundo colonial. A Sociedade de Africanistas, cujo secretário-geral é o fiel vice de Rivet, Paul Lester, assegura o estabelecimento de

${ }^{47}$ Ver a correspondência com os governadores das colônias (Museu de Etnografia do Trocadéro). Biblioteca do Museu do Homem. 
uma rede de correspondentes coloniais, e deve assegurar a chegada de informações do campo, sem deixar de estabelecer um controle sobre as publicações $^{48}$. O jornal dessa sociedade oferece, nos anos 30 , uma tribuna privilegiada aos etnógrafos ligados ao Museu do Trocadéro ${ }^{49}$.

Rivet estabelece algo semelhante a um monopólio sobre o conjunto daquilo que ele inclui em sua definição da "etnologia", e para isso se apóia na estrutura colonial (especialmente na hierarquia administrativa). Assim, em 1932, uma circular do Ministério das Colônias designa como correspondentes oficiais dos funcionários coloniais os organismos ligados a Rivet ${ }^{50}$, silenciando a respeito das organizações rivais, como a Escola de Antropologia, a Sociedade de Etnografia Louis Marin, ou ainda a Sociedade do Folclore Francês e do Folclore Colonial e a Sociedade de Antropologia de Paris (mesmo sendo Rivet membro destas duas), assim como as instituições científicas coloniais (Comitê de Pesquisas Históricas e Científicas da AOF, Academia das Ciências Coloniais, etc.). Tem-se aqui um processo de oficialização, no sentido de definição de uma ciência que é "oficial" na medida em que recebe o apoio solene do Ministério das Colônias.

No decorrer dos anos 30, Rivet se esforça em tornar-se interlocutor obrigatório junto aos governos coloniais. Ele realiza, assim, uma viagem à Indochina em 1932, a convite do governador-geral, e nessa ocasião procura estabelecer correspondentes locais. Esse aspecto aparece nitidamente no relatório acerca da viagem: "Nessa oportunidade, ele pôde percorrer toda a Indochina, o Iunan, Sião [atual Tailândia] e os Estados malaios, reunindo importantes coleções e centralizando os eforços a elas concernentes nas mãos do sr. Claeys, membro da Escola Francesa do Extremo Oriente, oficialmente encarregada da investigação permanente em etnologia." (LévyBruhl, 1933, p. 27) $)^{51}$.

${ }^{48}$ Essas sociedades possuem "comissões de publicação", nas quais geralmente deliberam representantes das instituições científicas oficiais, que dão o imprimatur aos trabalhos dos residentes nas colônias.

${ }^{49}$ Sobre as circunstâncias da criação da Sociedade dos Africanistas, permito-me remeter a L'Estoile (1997).

50 "Os residentes nas colônias que seguem ou empreendem estudos em etnologia serão os que preferencialmente se vincularão ao Instituto de Etnologia, o Museu de Etnografia e as sociedades científicas que dependem das atividades deles: Sociedade dos Americanistas e Sociedade dos Africanistas." (Circular do Ministério das Colonias, 21/7/1932).

${ }^{51}$ Claeys, arquiteto, é na realidade chefe do serviço arqueológico da Escola Francesa do Extremo Oriente. 
Em 1934, Rivet propõe ao governador-geral da AEF que seu discípulo, o doutor Pales, médico militar, passe a ser o "promotor da etnologia" (carta a Antonetti, 23/4/1934). O governador-geral dá seu consentimento para que Pales seja o "cérebro dessa organização de estudos", sob condição, no entanto, de que isso seja "em acréscimo à sua tarefa".

A correspondência entre o museu e as administrações coloniais ${ }^{52}$ é um bom testemunho dos reiterados pedidos às autoridades coloniais para obtenção de apoio às missões de exploração, pôr intérpretes à disposição dos encarregados destas, etc., mas também para reunir coleções etnográficas ou realizar investigações, como aquela, em 1932, sobre técnicas de produzir fogo.

O que se afirma cada vez mais, em nome da necessária "racionalização" e "coordenação", é o caráter piramidal e hierárquico dessa organização de pesquisa. Pode-se então, retomando os textos da época ${ }^{53}$, perceber uma clara oposição estrutural: de um lado, os termos que descrevem a situação desoladora da ciência colonial do passado, isolamento, dispersão, acaso, impotência, improvisação, superficialidade; de outro, aqueles que descrevem o futuro da pesquisa de além-mar: encontramos sobretudo verbos, como ordenar, elaborar, agrupar, classificar, organizar, coordenar, centralizar, dirigir, formar, ou o recurso incessante aos adjetivos "metódico", "racional", "sistemático" e "científico". Tal oposição visa certamente realçar o papel indispensável dos centros de pesquisa e incitar à sua unificação numa rede hierarquizada e centralizada ${ }^{54}$.

A expressão mais acabada dessa utopia científica centralizadora é o projeto do Museu do Homem, concebido precisamente como agrupamento do conjunto das instituições científicas, das coleções de crânios e de objetos etnográficos, de documentos diversos, das bibliotecas ${ }^{55}$. O museu deve ser simultaneamente uma "reserva" onde todos esses fatos, observações e objetos são arquivados, conservados e classificados, um conjunto de laboratórios, e também um local de exposição e de ensino. É a utopia de uma instituição central que visa à exaustividade, concentrando em todo um domí-

\footnotetext{
52 Bureau des Affaires Politiques de l'AEF [Archives]; Musée de l'Homme [Archives].

53 Notadamente, os do Congresso de 1937.

${ }^{54}$ Essa temática sugere a existência de uma afinidade eletiva com certo número de reformadores coloniais que defendem uma "racionalização" colonial: ver L'Estoile (2000).

55 Sobre o projeto do Museu do Homem, ver L'Estoile (2001).
} 
nio do saber a totalidade dos recursos materiais e humanos disponíveis ${ }^{56}$. Ao menos num primeiro momento, essa utopia parece tomar corpo: várias sociedades científicas - especialmente aquelas que estão mais ligadas à rede: americanistas, africanistas - têm suas sessões de encontro no novo museu, e reúnem aí suas bibliotecas. Assim também o Instituto de Etnologia é transferido rapidamente para o Trocadéro. No entanto, como assinala Lebovics, Louis Marin recusa essa agregação $0^{57}$.

Uma das características dessa modalidade específica de "institucionalização" é que ela repousa na participação de certo número de "colaboradores voluntários" 58 . Esse traço é recorrente tanto nas descrições do funcionamento do Museu de Etnografia do Trocadéro, nos anos 30, quanto nos projetos de organização das relações com o campo, nas colônias. Para simplificar, pode-se dizer que o modelo de base da divisão do trabalho repousa na colaboração estreita entre "especialistas", que coordenam e dão as instruções, e um conjunto de voluntários, que servem como mão-de-obra auxiliar na realização do trabalho.

Rivet nota que a "obra de reorganização" do Trocadéro foi possibilitada pelo "recrutamento selecionado de colaboradores voluntários" entre os alunos do Instituto de Etnologia (Rivet, 1936). A fórmula indica bem o papel essencial de tais voluntários ${ }^{59}$. Os "funcionários vinculados à cátedra do Museu" tiveram por função

organizar essa colaboração desinteressada, dividir as tarefas entre os benévolos, coordená-los de forma sistemática. Eles formaram os quadros de um pequeno exército de uns cinqüenta trabalhadores auxiliares e impuseram a seu entusiasmo e a sua atividade uma disciplina estrita que decuplicou sua produção; e talvez o aspecto mais

56 Incidentalmente, e baseando-nos na comunicação de François Jacq, notamos que esse movimento de concentração dos meios, do pessoal e do "instrumental" antecede em ao menos dez anos a criação de grandes laboratórios de física e química.

57 Podemos porém supor que essa recusa é menos motivada, como sugere Lebovics (1995), por uma oposição de ordem política, do que pela não aceitação da posição subordinada dentro do modelo proposto por Rivet.

58 É significativo que o termo "amador", elemento de desqualificação nas lutas científicas daqueles que se afirmam "profissionais", seja raramente empregado, e que sejam preferidos termos que valorizam mais os voluntários, os correspondentes, aqueles com disposição para colaborar, que eram empregados pelo museu no século precedente.

59 "Sem sua cooperação benévola e desinteressada, o Museu seria incapaz, com os recursos de que dispõe, de assumir uma tarefa que ultrapassava suas forças.” (Rivet, 1935, p. 135).

Horizontes Antropológicos, Porto Alegre, ano 9, n. 20, p. 265-302, outubro de 2003 
comovente do renascimento dos estudos etnológicos na França seja o fato de que este é em grande parte obra de tal trabalho coletivo. (Rivet, 1935, p. 135).

É notável que Rivet, médico militar por formação (Jamin, 1989), adote espontaneamente a linguagem e o modelo de organização do exército, quando descreve a tarefa de coordenação do "trabalho coletivo" no Museu do Trocadéro, do qual ele exerce, na qualidade de diretor, o comando geral.

Essa utopia parece extremamente mobilizadora; todos os testemunhos insistem quanto ao entusiasmo e à atividade febril do museu nos anos 30 . Os voluntários fazem fichas sobre os objetos, classificam as coleções, trabalham na fonoteca do museu, preparam as exposições ${ }^{60}$. Eles são, portanto, encarregados do trabalho de recepção e de classificação de todos os espécimes enviados das colônias ou trazidos pelas missões de coleta. O que é fundamental é que um número significativo desses "voluntários" se tornarão em seguida antropólogos profissionais: no início dos anos 30 encontramos, entre outros, Denise Paulme, Germaine Tillion, Germaine Dieterlen, Jacques e Georgette Soustelle, e ainda Jacques Faublée, futuro diretor do museu. Dito de outro modo, há então um continuum entre os "voluntários" e os "especialistas". Numa fase de expansão da disciplina, a infantaria de ontem são os "oficiais" de amanhã. Vê-se que a importação do modelo da "profissionalização", segundo o qual os "amadores" devem ceder lugar aos "profissionais", funciona aqui como uma tela, na medida em que não permite que se compreenda o processo em andamento, e em particular o papel de "socialização científica" preenchido pela participação voluntária nas atividades do museu do Trocadéro ${ }^{61}$. Poder-se-ia, ao contrário, ver no Trocadéro dos anos 30 um "centro mundano ligado ao meio intelectual", segundo palavras de Peltier (1991) $)^{62}$, e o ponto alto do "amadorismo", no sentido antigo do termo, isto é, da atividade daqueles que dispõem de meios materiais que lhes permitem, por lazer, interessar-se pelos objetos primitivos e pela etnografia. Parece, aliás, que ao menos parte desses "voluntários" não foi

60 Ver Université de Paris (1933).

61 Mais especificamente, notamos que os beneficiários das missões do Instituto de Etnologia eram, com freqüência cada vez maior, antigos voluntários.

62 O presidente da Sociedade dos Amigos do Trocadéro é o visconde de Noailles, mecenas da vanguarda artística e literária e amigo de Rivière.

Horizontes Antropológicos, Porto Alegre, ano 9, n. 20, p. 265-302, outubro de 2003 
recrutada do viveiro constituído pelos alunos do Instituto de Etnologia, e sim na rede pessoal de Rivière ${ }^{63}$, Parte desses amadores progressivamente se "profissionaliza" através da prática de trabalho, a começar pelo próprio Rivière ${ }^{64}$.

No projeto de Rivet (1935), o Museu do Homem devia ser completado, nas colônias, por uma rede de réplicas suas em miniatura, oferecendo assim um escoadouro para os alunos do instituto, que teriam essencialmente um papel de recrutamento e de ligação:

Esse estudo, que por muito tempo se deu ao acaso, pode e deve se tornar sistemático, agora que se criou um pequeno exército de pesquisadores especializados, graças ao ensino do Instituto de Etnologia da Universidade de Paris. É necessário que, em cada uma de nossas principais colônias, sejam constituídos centros de investigações etnológicas e museus locais, que permitam aos turistas, aos colonos e aos funcionários reunir in loco documentos e informações sobre os costumes das populações que eles visitam, com as quais trabalham, ou que administram.

Esses centros de estudo trabalhariam segundo um plano sistemático, agrupariam, coordenariam, orientariam e estimulariam todos aqueles com boa vontade, e, enfim, serviriam como órgãos de ligação com os centros metropolitanos.

Cada museu, na França e nas colônias, é concebido precisamente como um centro de coordenação e de impulsão, que deve "disciplinar" os "voluntários" e constituir seu próprio "pequeno exército" de trabalhadores auxiliares 65 . Rivet se esforça por criar centros locais, que seriam baseados nos museus etnográficos. Ele obtém um acordo inicial para a criação de um museu em Hanói, e outro, mais tarde, em Dakar.

63 Assim, por exemplo, Germaine Dieterlen conta que chegou ao Trocadéro em decorrência de um telefonema de G. H. Rivière, que lhe disse: "temos absoluta necessidade de voluntários" (La Soeur des Masques, 1996).

${ }^{64}$ Retrospectivamente, ele descreve a si mesmo, no momento em que começa sua "carreira profissional" no Museu de Etnografia, como "um homem de trinta anos, sem qualquer qualificação científica, cuja vocação musical não havia sido totalmente dissimulada por sua formação na Ecole du Louvre" (Rivière, 1968, p. 17).

65 Nota-se a recorrência da expressão "pequeno exército", que indica bem o fato de que é esse modelo que organiza ambos os casos. No entanto, aqueles que eram apresentados como "auxiliares" voluntários são aqui qualificados de "pesquisadores especializados". Vê-se bem, aqui, o caráter relativo e transitório das posições. 
É no momento da criação do Museu do Homem, inaugurado em 1937, que se afirma com mais força o modelo centralizador. No mesmo ano, no Congresso de Pesquisa Científica em Territórios Ultramarinos, a etnologia constitui por si só uma das sete seções, o que bem mostra ser ela, a partir de então, reconhecida como uma ciência colonial em pleno direito ${ }^{66}$. Os oradores insistem na necessidade de reforçar a "cooperação" entre instituições metropolitanas e coloniais, o que na prática significa o controle daqueles sobre estes, com o estabelecimento, entre eles, de laços orgânicos. As deliberações da sétima seção declinam esse programa: a deliberação de número 1 concerne à "organização da pesquisa etnológica nas colônias". As exigências que se seguem são características:

3o. Que os que trabalham como voluntários não especializados, funcionários, missionários, colonos e indígenas instruídos encontrem, junto aos organismos locais ou metropolitanos, notadamente do Museu do Homem, as informações (questionários, publicações) sem as quais seu trabalho não poderá alcançar seu pleno valor.

4‥ Que a organização da pesquisa etnológica nos territórios franceses ultramarinos se apóie essencialmente numa estreita ligação e numa troca continuada entre os organismos metropolitanos e locais.

O congresso, sob a presidência de Rivet, dá lugar a uma série de relatórios sobre a organização da pesquisa nas grandes zonas geográficas, que têm, cada uma, seu "delegado", todas ligadas à rede do Trocadéro ${ }^{67}$. A intervenção de Paul Mus, então diretor (interino) da Escola Francesa do Extremo Oriente, exprime de modo notável tal utopia centralizadora:

Não percamos de vista a idéia diretriz, a saber, a divisão do trabalho entre, de um lado, órgãos localizados na periferia, órgãos de pesquisa, de fixação e de transmissão ao centro, e, de outro lado, os órgãos centralizadores, órgãos de assimilação, de retransmissão sob forma elaborada, ao mesmo tempo que de estímulo, que respondem às informações a elas transmitidas com novas interrogações que só tais informações permitiram formular. (Mus, 1938).

A etnologia aparece aqui concebida como um vasto organismo, do qual o Museu do Homem seria ao mesmo tempo cérebro, estômago e coração

${ }^{66}$ Congrès de la Recherche Scientifique dans les Territoires d'Outre-Mer (1938).

${ }^{67}$ Griaule, para a África, Leenhardt para a Oceania, Soustelle para a América e, aqui, Decary para Madagascar. 
(sejam-me perdoadas tais aproximações com a fisiologia) ${ }^{68}$. É significativo que esse sistema de relés científicos - dessa altura em diante, institucionais e não mais individuais - esteja calcado na hierarquia administrativa. O coração da rede está na metrópole, na capital. Na sede de cada grupo de colônias, onde reside o governador-geral, encontra-se uma cabeça secundária (museu). Enfim, há um centro local em cada território.

Sempre se apoiando na hierarquia colonial, Rivet procura estabelecer ligações dos centros locais à rede. Em 1938, Théodore Monod, então assistente do Museu, é enviado para dirigir o IFAN, que substitui o Comitê de Estudos Históricos e Científicos da AOF. Igualmente, nos anos 40, as sociedades científicas locais dos Camarões e do Congo se transformam em centros locais do IFAN, administrativamente dependentes de Dakar.

Nada mostra melhor a pregnância desse modelo da divisão do trabalho que o grau extremo de refinamento ao qual ele será levado por Griaule. Em seu Método de Etnografia, Griaule expõe longamente as vantagens da "equipe dupla"69.

Uma expedição etnográfica bem concebida se compõe de duas equipes: a primeira vai a campo para lá se dedicar à pesquisa propriamente dita. A segunda se estabelece na metrópole e centraliza a documentação coligida. [Ela realiza] uma espécie de investigação de segundo grau, cuja base será formada pelos documentos provenientes da primeira. A documentação, com efeito, se constitui por fragmentos. [...] A segunda equipe estebelecerá para cada capítulo da pesquisa uma redação provisória, na qual os elementos serão ordenados, articulados, e os nexos entre eles, enfatizados. (Griaule, 1957, p. 25).

Ela produz assim um questionário, enviado a campo para aqueles que fazem a investigação.

68 Esse modelo centralizador será importado por G. H. Rivière no domínio do folclore francês, a partir da criação, em 1937, do Museu das Artes e Tradições Populares. Sobre o caráter estruturante de sua experiência no Trocadéro, ver Rivière (1968, p. 18); ver também Chiva (1987).

69 Já em 1937, Griaule propunha esse modelo para o IFAN recém-criado: "cada pesquisador ou grupo de pesquisa estará ligado a uma equipe metropolitana que receberá regularmente os documentos brutos da investigação, os elaborará, assinalará as lacunas e colocará à disposição do pesquisador questionários constantemente atualizados" (Griaule, 1938) Esse vaivém constante é supostamente capaz de assegurar o controle e o fluxo permanente de informações vindas da pesquisa de campo. 
Esse questionário tem a vantagem de, por um lado, estar estreitamente adaptado à investigação e, por outro, se valer das informações fornecidas pelas bibliotecas e os institutos metropolitanos de pesquisa. Assim tratado, o documento retorna aos investigadores, que têm tempo de retomá-lo em novas bases, ou ao menos sob ângulos um pouco diferentes. Assim que parece estar mais completo ou quando o novo impulso de pesquisa se esgota, o documento retorna à outra equipe. $\mathrm{O}$ vaivém se repete tantas vezes quantas forem necessárias para se obter uma descrição satisfatória. (Griaule, 1957).

Tal sistema parece dificilmente praticável, sobretudo em função das dificuldades de comunicação com as colônias, mas Griaule frisa que o método havia sido empregado com proveito nas missões de que fora encarregado. Essa visão do funcionamento da divisão do trabalho é com certeza idealizada, como indica uma carta de Déborah Lifchitz a Michel Leiris:

Quando Griaule partiu, não deixou conosco cópias de suas fichas; ele e os que com ele partiram não julgaram útil deixar-nos a par de seus trabalhos. Evidentemente, algumas de nossas investigações poderiam completar as suas, mas não queremos que eles trabalhem com as nossas fichas antes de nosso retorno, e se as enviarmos será difícil impedi-los. É bem mais simples, então, mantermos as fichas conosco. (Paulme, 1992, p. 76 [carta de Déborah Lifchitz a Michel Leiris, 19/ 4/1935]).

As duas investigadoras, afinal, enviarão as fichas à residência de Leiris, recomendando-lhe segredo!

O tema da "dupla equipe" mostra, em todo caso, o caráter estruturante do modelo da divisão do trabalho no interior das equipes de pesquisadores: o "pesquisador de campo", que recolhe os fatos, deve ser estimulado pelo "pesquisador metropolitano", que é o único em condições de elaborar as hipóteses, precisamente porque não é absorvido pelo trabalho de coleta ${ }^{70}$.

${ }^{70}$ É preciso sublinhar que essa divisão do trabalho não é, segundo Griaule, um simples declaque da oposição estudiosos de gabinete $\mathrm{x}$ pesquisadores de campo: ele especifica que "os membros da equipe metropolitana não se especializam como tal, mas são também pesquisadores que já foram a campo ou que irão algum dia. Uma simbiose contínua deve se estabelecer entre os de fora e os da metrópole" (Griaule, 1957). 
Tal forma de divisão do trabalho implica, desse modo, um monopólio do trabalho de interpretação e de teorização no nível superior de generalização, que se opõe radicalmente ao modelo malinowskiano, segundo o qual a observação constitui necessariamente uma operação teórica. O ideal é portanto aquele das monografias completas, cuja acumulação permitirá aos cientistas do futuro elaborar leis gerais. O objetivo é chegar primeiro a um inventário enciclopédico. Como diz Griaule, "trata-se de estabelecer o arquivo total da humanidade, procedendo por monografias. [...] Só então a sociologia poderá proceder às generalizações e estabelecer leis" (Griaule, 1957, p. 5).

O período entre guerras parece assim assistir à afirmação de um consenso em torno do primado da coleta de fatos. Segundo Mauss, as tarefas descritivas são de fato mais urgentes do que as tarefas teóricas, na medida em que os fatos sociais das "sociedades inferiores" estão em processo de desaparição.

Ora, eles são preciosos para a ciência futura, mais ainda que para a nossa. Temos o dever absoluto não somente de compreendê-los como também, mesmo sem os compreender, dar o melhor de nós para constatá-los, descobri-los e fazer que sejam registrados. Essa é nossa responsabilidade perante a ciência futura, assim como perante nosso país e as populações mesmas. É por isso que Lévy-Bruhl, Rivet e eu temos trabalhado tanto para o Instituto de Etnologia da Universidade de Paris. Este é, aliás, o caso de todas as ciências da natureza. Elas necessitam de multidões de colaboradores. A pesquisa e o conhecimento de fatos sempre mais numerosos decorrem de suas próprias exigências. (Mauss, 1969, p. 445-446; grifo meu).

Uma vez mais, Mauss afirma que o objetivo essencial do Instituto de Etnologia é formar colaboradores capazes de "registrar" os fatos descobertos pelos estudiosos acadêmicos. Não se poderia dar melhor expressão à idéia de que o progresso da ciência está baseado na acumulação de fatos, no crescimento do "número de realidades conhecidas". Além disso, conclui Mauss, "a parte descritiva de nossas ciências tem grandes e fortes atrativos, tão fortes quanto os da botânica e da zoologia" (Mauss, 1969), enquanto para Griaule "deve-se aplicar à pesquisa de todo e qualquer fato social e ao conhecimento de todas as sociedades humanas o mesmo ardor com que os 
naturalistas estabelecem uma lista exaustiva dos insetos e das plantas" (Griaule, 1957, p. 4).

Henri Labouret, que se mostra um zeloso coletor de objetos para o museu do Trocadéro em suas missões na AOF (1932) e nos Camarões $(1934)^{71}$, adota da mesma forma uma postura de humilde auxiliar que sabe ater-se a seu papel de observador e de "coletor de fatos". Na introdução à sua monografia As Tribos do Ramo Lobi, publicada pelo Instituto de Etnologia em 1931, ele trata de precisar o ponto: "Preocupado, antes de mais nada, em trazer à ciência fatos precisos, abstive-me de discutir e de interpretar os fenômenos descritos." (Labouret, 1931).

De um modo geral, é o modelo de organização da pesquisa que produz uma etnografia bem descritiva, bem factual (e, hoje em dia, árida ${ }^{72}$ ), cujo ideal é a monografia exaustiva, mas que pode também tomar uma forma fragmentária: descrição de um utensílio, de um rito de circuncisão ou de colheita, coleta de alguns provérbios ou termos de vocabulário, registro de cantos ou de músicas, etc. ${ }^{73}$ Esses trabalhos são concebidos desde o início como uma contribuição parcial a uma obra coletiva, visando produzir uma espécie de enciclopédia dos povos do mundo ${ }^{74}$. A etnografia constitui um "arquivo" para a posteridade, destinado a ser elaborado por outros, material para uma análise secundária que será talvez realizada pelas gerações futuras.

\section{Conclusão}

Assim, dos seminários de Mauss, no início do século XX, até o ensino de Griaule, nos anos 50, encontramos, sob diferente formas, esse Leitmotiv da divisão do trabalho, que opõe o estágio da descrição, da coleta de fatos e da monografia ao da síntese, da generalização e da descoberta de leis. Os

\footnotetext{
71 As vitrines atuais (em 1999) de Camarões e da Costa do Marfim, no Museu do Homem, são em grande parte constituídas por objetos coletados por Labouret.

${ }^{72} \mathrm{O}$ que torna hoje difícil a leitura desses textos é termos perdido o quadro interpretativo dentro do qual fazem sentido.

${ }^{73}$ É precisamente a essa estrutura que correspondem as Notas Africanas, publicadas pelo IFAN, cujo n.1, mimeografado, sai em janeiro de 1939: elas contêm "instruções" e também "observações" diversas, geralmente fragmentárias.

${ }^{74}$ Esse espírito enciclopédico não está morto, como evidencia o recente Dicionaire des Peuples. Sociétés d'Afrique, d'Asie et d'Océanie [Dicionário dos Povos. Sociedades da África, da Ásia e da Oceania] (Tauzier, 1998).
} 
anos 30 viram um esforço de criação de um sistema racionalizado de divisão do trabalho, que pretendia ser sistemático e centralizado. Para que se tenha uma idéia de como se afiguraria essa utopia tão afastada da visão romântica da etnologia solitária, é necessário imaginar uma espécie de INSEE etnológico $^{75}$ : um modelo de organização burocrática da pesquisa, baseado numa divisão do trabalho levada ao extremo, com um centro que controla, estimula, coordena e organiza os dados, com delegação de tarefas e uma rede de colaboradores locais recrutados e formados, recebendo instruções de Paris e enviando de volta objetos e "fatos" científicos, devidamente descritos e rotulados, que podem em seguida ser classificados e sintetizados por pesquisadores do Museu do Homem.

Assim, enquanto na Grã-Bretanha a "profissionalização" da disciplina foi acompanhada da exclusão dos "amadores", relegados a um estado obsoleto da disciplina, o modelo de divisão do trabalho, dominante na França, exigiu, ao contrário, o recrutamento de "multidões de colaboradores" e favoreceu o estabelecimento de um continuum entre os profissionais e os "auxiliares". A institucionalização da etnologia na França se fez não por uma ruptura, mas por inclusão, em graus diversos, de um número considerável de colaboradores voluntários, boa parte dos quais se beneficia da expansão da disciplina e progressivamente vai se estabelecendo no que vem a se tornar uma carreira, estando vinculados ao museu ou aos institutos de pesquisa nas colônias (IFAN, ORSTOM), e depois ao CNRS ou à 6a seção da EPHE, que depois se tornará a EHESS ${ }^{76,77}$. Desse modo, em lugar de uma substituição de amadores por profissionais (conforme, por exemplo, o modelo da história no princípio da Terceira República), o fenômeno maior foi, aqui, o processo de "profissionalização" de uma parte mesma desses amadores.

A utopia enciclopédica do "arquivo total da humanidade" perdeu progressivamente o potencial de mobilização, ainda que seus efeitos se fizessem

75 O INSEE, Institut National de la Statistique et des Etudes Economiques [Instituto Nacional de Estatística e de Estudos Econômicos], é mais ou menos equivalente ao que é, no Brasil, o IBGE - Instituto Brasileiro de Geografia e Estatística (N. de T.).

76 IFAN, Institut Français pour 1'Afrique Noire [Instituto Francês para a África Negra]; ORSTOM, Office des recherches scientifiques et techniques outre-mer [Serviço de pesquisas científicas e técnicas ultramarinas]; CNRS, Centre National de la Recherche Scientifique [Centro Nacional de Pesquisa Científica]; EPHE, Ecole Pratique des Hautes Etudes (N. de T.).

77 Essa entrada é facilitada por o diploma do Instituto de Etnologia ser relativamente acessível, ao passo que a obtenção de um doutorado se torna um pré-requisito na Grã-Bretanha.

Horizontes Antropológicos, Porto Alegre, ano 9, n. 20, p. 265-302, outubro de 2003 
sentir de modo duradouro no tipo de prática científica dos antropólogos, em particular por se terem cristalizado nas instituições da disciplina (Museu do Homem, CNRS, universidade). A respeito da famosa tripartição estabelecida por Claude Lévi-Strauss (1958) - entre a etnografia, que deve contentar-se com descrições monográficas, coletando "fatos" e se recusando a interpretá-los, a etnologia, que realiza uma síntese num primeiro nível (regional, ou respeitante a alguma técnica), e a antropologia, ciência comparativa - podemos, portanto, perguntar-nos se ela afinal não é uma reprodução da estrutura da divisão do trabalho, que se expressa notadamente no Museu do Homem, e se ela assim não pereniza, transformada, essa estrutura ${ }^{78}$. Constata-se também, notavelmente, que o Laboratório de Antropologia Social retoma, com ajuda de outra tecnologia, importada dos Estados Unidos (o Human Relations Area Files [Arquivos de Relações Humanas por Área]) e orientada para a catalogação em fichas do conjunto das culturas humanas, o projeto desmedido do "arquivo total da humanidade" 79 .

Traduzido do francês por Amir Geiger

\section{Referências}

BALANDIER, G. Aspects de l'évolution sociale chez les Fang du Gabon. Cahiers Internationaux de Sociologie, IX, n. 7, 1950.

BAZIN, Jean. Interpréter ou décrire: notes critiques sur la connaissance anthropologique. In: REVEL, J.; WACHTEL, N. (Org.). Une école pour les sciences sociales. Paris: CERF: EHESS, 1996. p. 401-420.

BLANCKAERT, C. Collecter, observer, classer. In: Le muséum au premier siècle de son histoire. Paris: Muséum National d'Histoire Naturelle, 1993. p.159-162.

\footnotetext{
78 Ver especialmente Lévi-Strauss, Place de l'anthropologie dans les sciences sociales et problèmes posés par son enseignement [Lugar da antropologia nas ciências sociais e problemas colocados por seu ensino] (1958, cap. XVII).

79 O arquivo instalado desde 1962 na biblioteca do Laboratório de Antropologia Social contém aproximadamente 4.500.000 fichas classificadas, correspondentes a "335 etnias ou unidades culturais" (fonte: "Apresentação" da biblioteca do Laboratório de Antropologia Social). Esse arquivo dos "HRAF paper files", hoje em parte disponível na Internet, "sistema de pesquisa, de análise, de classificação, de arquivamento de dados etnográficos", foi criado em 1949, em seqüência ao "Cross-Cultural Survey" de 1937, em Yale. Ver HRAF News (1999).
} 
BONNEUIL, C. Le Muséum National d'Histoire Naturelle et l'expansion coloniale de la IIIème République (1870-1914). Revue d'Histoire de la France d'Outre-mer, t. 86, n. 322-323, p. 143-169, 1999.

BOURGUET, M. N. La collecte du monde: voyage et histoire naturelle (fin XVIIème-début XIXème siècle). In: Le muséum au premier siècle de son histoire. Paris: Muséum National d'Histoire Naturelle, 1993.

BUREAU DES AFFAIRES POLITIQUES DE L'AEF [Archives]. Centre des archives d'Outre-mer (CAOM), Aix-en-Provence.

CHIVA, Isaac. Entre livre et musée. In: CHIVA, I.; JEGGLE, U. Ethnologies en miroir: la France et les pays de langue allemande. Paris: MSH, 1987.

CONGRÈS de la Recherche scientifique dans les Territoires d'Outre-Mer: Exposition Internationale de Paris, 1937. Paris: Association ColonieSciences, 1938.

DESCOLA, Philippe. Anthropologie structurale et ethnologie structuraliste. In: REVEL, J.; WACHTEL, N. (Org.). Une école pour les sciences sociales. Paris: CERF: EHESS, 1996. p. 127-143.

DIETERLEN, Germaine. Tendances de l'ethnologie française (II). Cahiers Internationaux de Sociologie, XXVII, p. 23-26, 1959.

DRESCH, Paul; JAMES, Wendy; PARKIN, David J. (Org.). Anthropologists in a wide world. New York: Berghahn, 1999.

IFAN. Instructions sommaires pour les collecteurs d'objets ethnographiques. Paris: Musée d'Ethnographie/Mission Scientifique Dakar-Djibouti, 1931.

GRIAULE, Marcel. Introduction méthodologique. Minotaure, n. 2 (Mission Dakar-Djibouti: 1931-1933), 1933.

GRIAULE, Marcel. Méthode de l'ethnographie. Paris: PUF, 1957.

HRAF News: From the president: HRAF at 50. HRAF News, p. 1-2, spring/ summer 1999.

JAMIN, Jean. Le musée d'ethnographie en 1930: l'ethnologie comme science et comme politique. In: La Muséologie selon GH Rivière. Dunod, 1988.

JAMIN, Jean. Le savant et le politique: Paul Rivet (1876-1958). Bulletins et Mémoires de la Société d'Anthropologie de Paris, t. 1, n. 3-4, p. 277294, 1989. 
KUKLICK, H. The savage within: the social history of British Anthropology 1885-1945. Cambridge: Cambridge University Press, 1992.

LA SOEUR des masques [Germaine Dieterlen fala de seu trabalho entre os Dogon e de sua carreira]. Realização de Marie Cipriani-Crauste e Mariagrazia Fellini. França/Itália, 1996. 30 min.

LABOURET, Henri. Les tribus du rameau Lobi. Paris: Institut d'Ethnologie, 1931.

LABOURET, Henri. Ethnologie coloniale: un programme de recherches. Outre-Mer, IV, n. 1, p. 48-89, 1932.

LEBOVICS, Herman. La vraie France: les enjeux de l'identité culturelle, 1900-1945. Berlin, 1995.

L'ESTOILE, Benoît de. The "natural preserve of anthropologists": anthropology, scientific planning and development. Information sur les Sciences Sociales, v. 36, n. 2, 1997.

L'ESTOILE, Benoît de. Science de l'Homme et domination rationnelle: ethnologie et politique indigène en Afrique coloniale française. Revue de Synthèse, n. 3/4, p. 291-323, 2000. [edição brasileira: Ciência do Homem e "dominação racional”: saber etnológico e política indígena na África Colonial Francesa. In: L'ESTOILE, B.; NEIBURG, F.; SIGAUD, L. (Org.). Antropologia, impérios e Estados nacionais. Rio de Janeiro: Relume-Dumará, 2003. p. 61-93.]

L'ESTOILE, Benoît de. Des races non pas inférieures, mais différentes: de l'Exposition Coloniale au Musée de l'Homme. In: BLANCKAERT, Claude (Org.). Politiques de l'anthropologie: discours et pratiques en France (1860-1940). Paris: L'Harmattan, 2001.

L'ESTOILE, Benoît de. Le musée des Arts premiers face à l'histoire. Arquivos do Centro Cultural Calouste Gulbenkian, Paris-Lisboa, n. 4344, 2003.

LÉVI-STRAUSS, Claude. Anthropologie Structurale. Paris: Plon, 1958. [edição brasileira: Antropologia estrutural. Rio de Janeiro: Tempo Brasileiro.] LÉVY-BRUHL, Lucien. L'Institut d'Ethnologie de l'Université de Paris. Revue d'Ethnographie et de Traditions Populaires, xxiii-xxiv, p. 1-4, 1925. LÉVY-BRUHL, Lucien. La mentalité primitive [The Herbert Spencer Lecture, delivered at Oxford, 29 May 1931]. Oxford: Clarendon Press, 1931. 
LÉVY-BRUHL, Lucien. [Carta à redação, de 5/12/1931]. Bulletin de la Société des Recherches Congolaises, n. 17, 1932.

LÉVY-BRUHL, Lucien. In: UNIVERSITÉ DE PARIS. Annales de l'Université de Paris, 1933.

MALINOWSKI, Bronislaw. Les Argonautes du Pacifique Occidental. Paris: Gallimard, 1963. [edição brasileira: Os argonautas do Pacífico Ocidental. São Paulo: Abril. (Coleção Os Pensadores).]

MALINOWSKI, Bronislaw. An ethnographic theory of Language and some practical corollaries. In: MALINOWSKI, B. Coral Gardens and Their Magic. Bloomington: Indiana University Press, 1965. v. 2.

MARCEL, Jean Christophe. Maurice Halbwachs à Chicago ou les ambiguïtés d'un rationalisme durkheimien. Revue d'Histoire des Sciences Humaines, 1, p. 47-67, 1999.

MARTONNE, Edouard de. Le savant colonial. Paris: Larose, 1930.

MAUSS, M. Oeuvres III. Organisation V. Karady. Paris: Editions de Minuit, 1969. [Republicação, entre outros, de: Leçon d'ouverture à l'enseignement de l'histoire des religions des peuples non civilisés, artigo publicado na Revue de l'Histoire des Religions, em 1902; Essai d'une instruction pour l'étude sociologique des sociétés indo-chinoises, publicado em Premier Congrès International des études d'Extrême-Orient, Hanoi (1902): Compterendu analytique des séances, em 1903; L'ethnographie en France et à l'étranger, artigo publicado na Revue de Paris, em 1913; La Sociologie, artigo publicado em La Science Française, em 1933]

MAUSS, M. Manuel d'Ethnographie. Organisation D. Paulme. Paris: Payot, 1989. [Republicação da edição original, de 1947]

MONOD, Théodore. In: IFAN. Instructions sommaires, III: conseils aux chercheurs. 4è édition. Dakar, 1954.

MUS, Paul. L'Indochine. In: CONGRÈS de la Recherche scientifique dans les Territoires d'Outre-Mer: Exposition Internationale de Paris, 1937. Association Colonie-Sciences, 1938.

MUSÉE DE L'HOMME [Archives]. Paris.

PAULME, Denise. Lettres de Sanga à André Schaeffner [suivi des Lettres de Sanga, de Deborah Lifchitz et Denise Paulme à Michel Leiris]. Paris: Fourbis, 1992. 
PELTIER, Philippe. Océanie. In RUBIN (Org.) Le primitivisme dans l'art du XXème siècle: les artistes modernes devant l'art tribal. Paris: Flammarion, 1991. p. 98-123.

POUPON, Alfred. Méthodes actuelles en matière d'ethnologie. Bulletin de la Société des Recherches Congolaises, n. 13, 1931.

POUPON, Alfred. Analyse des notes d'ethnographie néo-calédoniennes de M. Leenart. Bulletin de la Société des Recherches Congolaises, n. 16, p. 37-62, 1932.

PREMIER Congrès International des études d'Extrême-Orient, Hanoi (1902): compte-rendu analytique des séances. Hanoi: F. H. Schneider, 1903. PROUTEAUX, Maurice. Quelques exemples de l'utilité pratique des études ethnologiques. Journal de la Société des Africanistes, p. 195-206, 1932. PROTEAUX, Maurice. [Arquivos pessoais]. Centre des archives d'Outremer (CAOM), Aix-en-Provence.

REVEL, J.; WACHTEL, N. (Org.). Une école pour les sciences sociales. Paris: CERF: EHESS, 1996.

RIVET, Paul. In: UNIVERSITÉ DE PARIS. Annales de l'Université de Paris, 1935.

RIVET, Paul. Ce qu'est l'ethnologie. In FEBVRE, L. (Org.). L'Espèce Humaine. Paris: Comité de l'Encyclopédie: Librairie Larousse, 1936. (L’Encyclopédie Française, v. IX). Não paginado.

RIVIÈRE, G. H. My experience at the Musée d'Ethnologie. Proceedings of the Royal Anthropological Institute of Great Britain and Ireland. 1968. p. 17-21.

STOCKING, George. After Tylor. Madison: University of Winsconsin Press, 1996.

TAUZIER, J. C. (Org.). Dictionnaire des Peuples. Sociétés d'Afrique, d'Asie et d'Océanie. Préface de M.Godelier. Introduction D. de Coppet. Larousse, 1998.

UNIVERSITÉ DE PARIS. Annales de l'Université de Paris, 1933.

Recebido em 27/07/2003

Aprovado em 20/08/2003

Horizontes Antropológicos, Porto Alegre, ano 9, n. 20, p. 265-302, outubro de 2003 